(20)

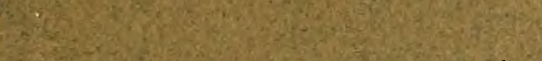




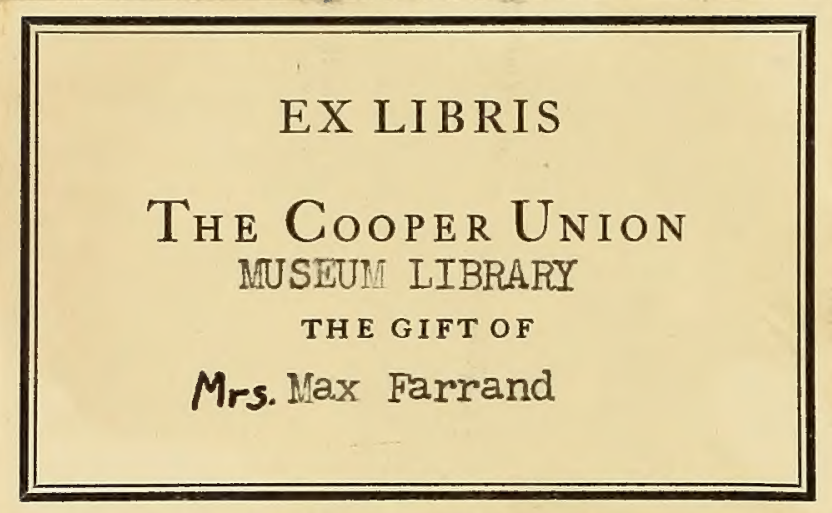










\section{THE ANNA DIKE SCOTT COLLECTION OF OLD LACE}



THIS COLLECTION, MADE BY THE LATE MRS. THOMAS A. SCOTT

IS NOW IN THE POSSESSION OF HER DAUGHTER

MARY SCOTT NEWBOLD

OF

CROSSWICKS HOUSE

JENKINTOWN, PENNSYLVANIA

MDCCCCV 
Printed for private circulation.

Edition limited to fifty copies.

Number Eleolu

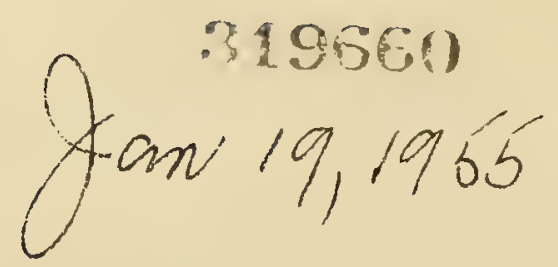




\section{INTRODUCTION}

7 HE collection of old lace herein catalogued

1 is one of exceptional interest, gathered as it has been, quietly and always reflecting the intelligence and true instincts of the connoisseur. The collection is in no sense a chronological one, it is confined chiefly to the laces of the seventeenth and eighteenth centuries, which centuries mark the apogee in the art of lace making. Its excellence consists in the number, variety and richness of its specimens, the examples of ecclesiastical and court laces being especially notable and complete. The collector was distinctly catholic in her taste and was fortunate in procuring rare examples representative of the principal schools of both point and pillow lace. Thus unconsciously, as it were, the collection has gradually become one that ranks in importance with those of the European museums.

SAMUEL BRIDGE DEAN 



\section{PREFACE}

$7 \mathrm{HE}$ study of old lace is an absorbing and interesting one on account of the important place which lace and lace making filled in the history of the Arts from the sixteenth century to the end of the eighteenth, and also because of its being one of the most beautiful of all fabrics, one in which the best effort of the designer and the greatest skill of the workman were brought into requisition. Old lace suggests the pomp, chivalry and romance of a golden age, for the Church and Court first encouraged the making of lace and created a demand for it. Later, when the production became more general, large numbers of people were employed in the industry, and the revenues derived added greatly to the prosperity of the countries where the lace was made. Much of the beauty of old lace is due to the fine texture of the flax or thread from which it was made, and also to the actual workmanship, in 
which the matter of time was not considered. Some of the richest Venetian laces required the constant labor of many years to complete.

With the advent of machinery, the incentive for making lace by hand was gradually crushed out. Lace industries have been revived from time to time, and although the results show conscientious effort, the lace is lacking in the delicacy and charm which characterized the old-time fabric.

Boston

April, I905 


\section{VENETIAN}

70 Venice belonged the distinction of having introduced the art of making point lace, and during the seventeenth century she led the world in the richness of her points. Although at that time the Republic had lost much of her prestige and her people were deeply engaged in wars, a keen interest was still manifested in the advancement of her lace industries. The seventeenth century points marked the zenith of the evolution of the art of point lace making. This art began in the sixteenth century with the Punto a Groppo and was followed by the Tirato, Tagliato, Maglia, Reticella, and Punto in Aria; all of these classes quickly succeeded one another and brought the lace industry up to the first part of the seventeenth century. Then began to be made the great classes of Point de Venise, Punto Tagliato a Fogliami, Punta Rosa, Point de Venise à réseau, and last of all Burano lace. All of these latter classes of lace are represented in this collection. Of the earlier 
laces the collection contains Punto a Groppo, or Punto Gotico, a lace made entirely of knots; Reticella, the last of the geometric class; and Punto in Aria, which was the first class of lace made from no foundation. In constructing Venetian point the pattern was first drawn on parchment; a thread was then secured to the various outlines of the details; all spaces thus enclosed were filled in with needle work, the completed details being joined by brides, or, in the case of Point de Venise à réseau or Burano, by a fine ground.

Point de Venise belonged to a class by itself. The details of the pattern were usually flat, and hence the lace was sometimes called Point Plat de Venise. The brides used to connect the details were a decorative feature of the lace.

Punto Tagliato a Fogliami, or Gros Point de Venise, and Punta Rosa belong to the punto a vilievo class: so named owing to the heavily stuffed cordonnet and other raised devices, these reliefs in turn being enriched with picots.

The, patterns of these laces were usually of the flowing, foliated scroll of the Renaissance. The waxy effect of the toilé was owing to its being very closely wrought, and to the glossiness of the flax from which it was made. Punta Rosa was a modification of the Gros Point de Venise and was sometimes called Point de Neige. The brides in 
these laces were used only to connect the details, and were in no sense a feature of the decoration.

Point de Venise à réseau and Burano belonged to the réseau class. The patterns of the former lace consisted principally of conventionalized foliated forms showing Rococo influence. The toilé had no cordonnet. The cordonnet of the Burano consisted of a strand of thread whipped over and over. The ground of these laces resembled that of the Point d'Alençon, but in the Point de Venise à réseau the meshes were not, as in Point d'Alençon, formed in lines across the lace. The patterns of the Burano closely followed the style of those of the Point d'Alençon. The making of the Venetian points ceased with the close of the eighteenth century. 


\section{VENETIAN}

I

Cord and Tassels.

I6th century. An early example of button-holed or knotted work, classed as Punto a Groppo.

2

Length: Reticella and Punto in Aria.

I6th century.

In the early Italian laces of the geometric class the band was usually made separately from the border, and the pattern of both band and border often showed no similarity of design.

Length, 30 inches; width, 5 inches.

3

BORDER: Punto Tagliato a Fogliami.

Early I 7 th century. The toile in this example is loosely worked. Some of the details are outlined by a tape instead of a raised cordonnet.

Length, 2 yards 4 inches; width, I inch. 
Border: Punto Tagliato a Fogliami.

Middle 17 th century.

Pattern shows scroll of the Renaissance ornamented with pomegranates and leafage, details enriched with a raised cordonnet à picots, and connected with brides picotées.

Length, I yard $I 7$ inches; width, 4 inches.

5

Border: Punto Tagliato a Fogliami.

Early i 7 th century. An early and crude example of this class of lace.

Length, 28 inches; width, 6 inches.

6

Border: Punto Tagliato a Fogliami.

Early i 7 th century. Pattern of pinks with conventional foliage, showing a slight Oriental influence.

Length, 3 yards $2 \mathrm{x}$ inches; width, 3 inches.

7

Border: Punto Tagliato a Fogliami.

Middle I 7 th century.

Pattern consists of branched and foliated scrolls with vigorous treatment of details, in the toilé of which are introduced a great variety of intricate stitches. The cordonnet is in high relief, and on 
it are superposed picots. The various details of the pattern are joined together with brides. This lace is also known as Gros Point de Venise.

Length, 4 yards I 5 inches; width, 9 inches.

8

Border: Punta Rosa. Late i 7 th century. Pattern consists of graceful scrolls and blossom forms, with fillings of an infinite variety. 'Details connected by brides and double brides picotées.

Length, 4 yards $1 \mathrm{I}$ inches; width, 6 inches.

9

Garniture of three pieces: Punta Rosa.

Late I 7 th century.

A continuous series of Arabesque scrolls furnish the foundation of the pattern, and on these scrolls, at frequent intervals, are superposed floral devices of microscopic workmanship. These devices have a cordonnet in high relief, enriched with picots. Details of the pattern are connected by brides picotées. This lace is also known as Point de Neige.

Length, 5 yards; width, 4 inches.

IO

Garniture of three pieces: Punta Rosa.

Late $\mathrm{I}$ th century.

Delicate scroll pattern on which are superposed foliated forms embellished with picots.

Length, 2 yards 18 inches; width, 3 inches. 
Flounce And Border: Point Plat de Venise.

Middle 17 th century. The motif of the repeating pattern consists of three upright, foliated forms placed one above the other, and surrounded by interlacing scrolls. Details connected by brides picotées.

Flounce. Length, 3 yards 18 inches; width, $I_{3}$ inches.

Border. Length, 3 yards 18 inches; width, 3 inches.

\section{2}

Collar: Point Plat de Venise. Late I 7 th century. Crude example of this class of lace.

I 3

Jabot and Border: Point Plat de Venise.

I 7 th century.

Pattern of fine, narrow scrolls of a tape-like toile intermixed with conventional flower devices. The details are connected by brides picotées.

Border. Length, I yard 5 inches.

I 4

Garniture: Point de Venise.

Middle I 7 th century.

Floral forms and conventional ornaments are used without definite design, the details being connected by brides picotées.

Length, 5 yards 16 inches; width, 3 inches. 
Border: Point de Venise. Middle I 7 th century. Foliated and other forms are placed without relation to each other. The details of ornament are joined together with brides embellished with picots. Length, 2 yards 27 inches; width, 7 inches.

I6

JABOT AND TWO PIECES: Point de Venise $\grave{a}$ réseau.

Late 17 th century.

Flamboyant foliated pattern in Rococo style. Toile of extraordinary fineness. The details are connected by a réseau, which is the same as that used in Burano lace.

Illustration.

I 7

BARBE: Burano.

Early i 8th century.

Center ornamented by a pattern of conventional fruit and flowers, the details of which are connected by a fine réseau.

I 8

BORDER: Point de Venise à brides picotées.

Late i 7 th century.

Large details arranged without forming a regular pattern, the toilé of the details presents many open spaces which are filled in with elaborate $\dot{a}$ jours.

Length, 24 inches; width, $2 \frac{1}{2}$ inches. 
Jabot. Point de Venise à réseau Number Sixteen 

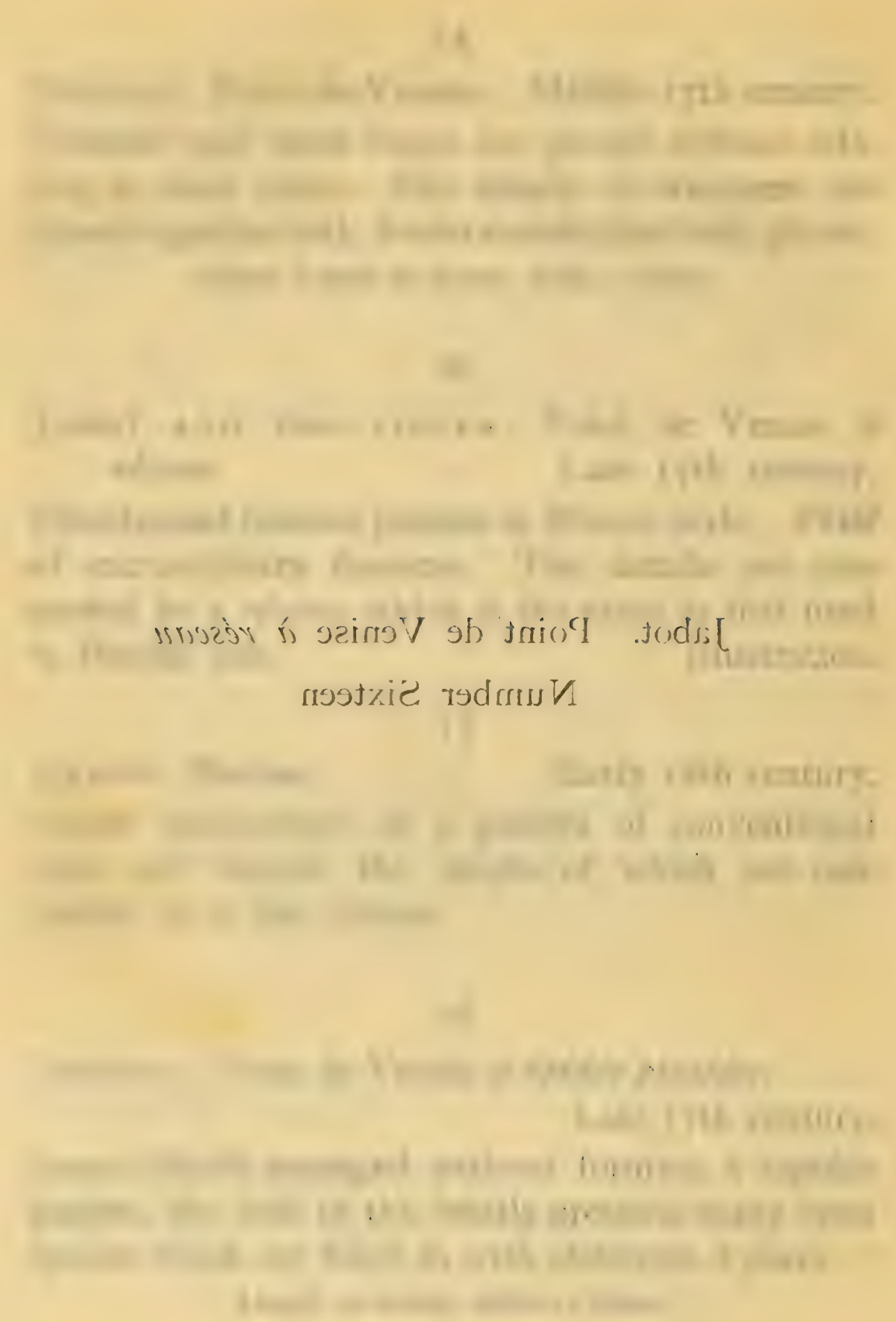


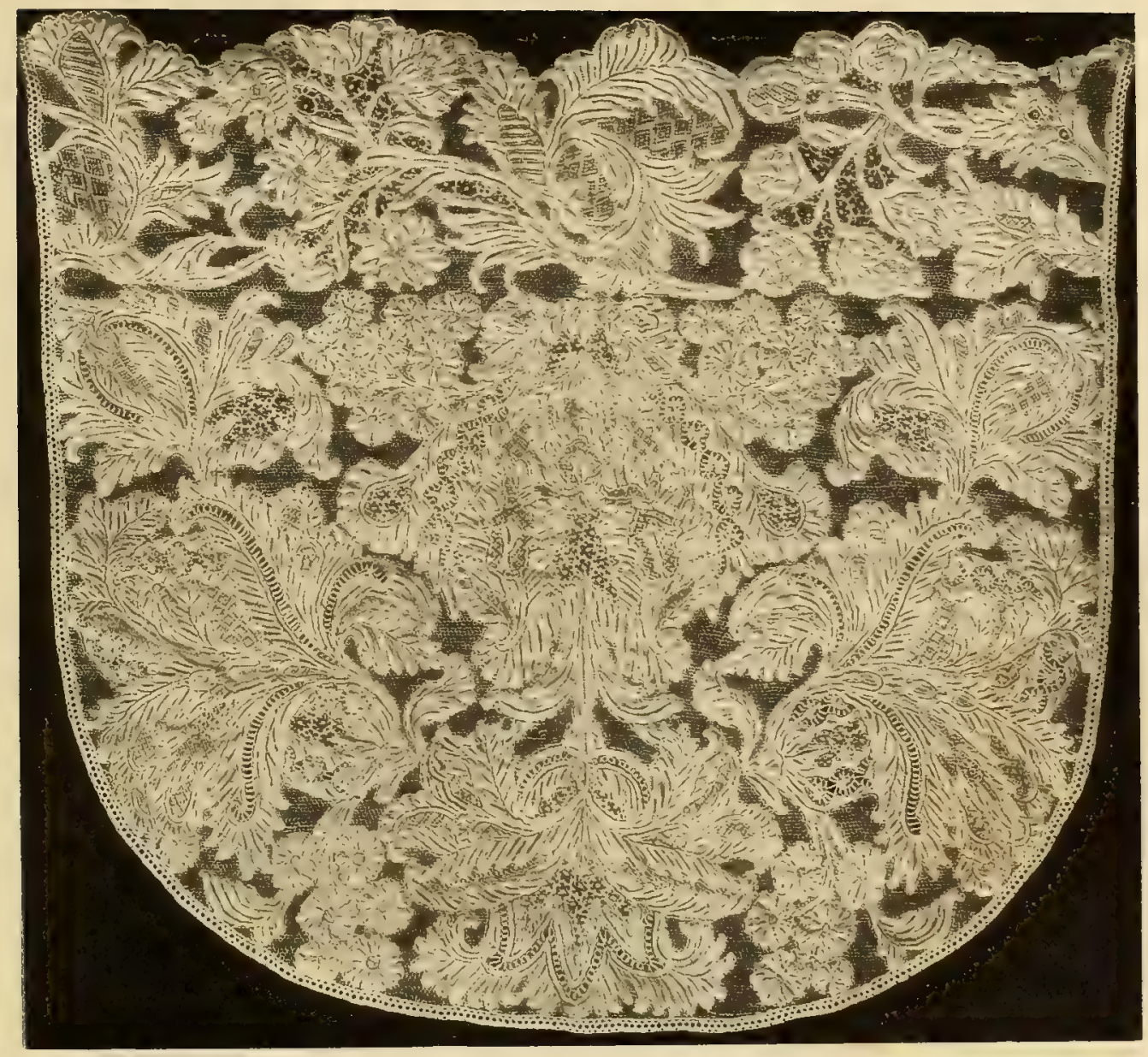



19

Two pieces Burano. Early i 8 th century. Pointed pattern of quatrefoils, connected by a réseau of exceeding fineness. Rich border of scroll work and floral design.

Length, 17 inches; width, $2 \frac{1}{2}$ inches.

\section{I9a}

Two pieces Burano. Late i 8 th century. Flowerets are scattered over the ground. Panel border enclosing elaborate $\grave{a}$ jours. 


\title{
GENOESE AND MILANESE
}

\begin{abstract}
T ARDLY less important than the Venetian points were the pillow laces of Genoa and Milan. These laces may almost be classed together, as both were of the tape-guipure variety. The designs in Genoese lace were, as a rule, indefinite, a feature being the winding and interlacing of the tape-like toile, suggesting the coral. The details were connected by brides and sometimes by a plaited mesh. The pattern of the Milanese was composed of flowing, graceful scroll work, varied by escutcheons and strap-like forms, these details being joined by a plaited mesh and occasionally by brides. Genoese and Milanese laces were largely used for ecclesiastical purposes, their heavy and decorative nature making them especially appropriate for the uses of the Church.
\end{abstract}




\section{GENOESE}

BORDER. $\quad$ Late I 7 th century.

Irregular pattern, consisting of a tapey toile, fashioned in coral forms. Details are connected by a hexagonal mesh.

Length, I yard 22 inches; width, Io inches.

2 I

PAIR OF Cuffs. Middle i 7 th century. Decorated with sprays of branching coral, hexagonal plaited mesh.

22

Collar. Middle I 7 th century. Conventional coral pattern of interlacing loops and scrolls.

BORDER.

23

Portion from a larger piece. Ornamented with irregular forms filled in with modes.

Length, 2 yards 14 inches; width, 3 inches. 
BORDER.

Pattern of upright, individual sprays, of branching coral devices. Details connected by a réseau. Scalloped edge.

Length, 4 yards 18 inches; width, 8 inches.

BORDER. 25

Repeating pattern of escutcheons and scrolls. Details connected by a mesh.

Length, 8 yards 5 inches; width, 3 inches.

26

BORDER.

Late 17 th century. The motif is a vertical, repeating pattern of escutcheon-like forms, the spaces between being filled with interlacing scrolls.

Length, 3 yards 25 inches; width, 7 inches.

BORDER.

27 Tape-like toilé formed into irregular, branching scrolls with trefoil terminations.

Length, 3 yards 25 inches; width, 6 inches.

28

Collar and Cuffs.

I 7 th century. Ornamented with scroll work. 
BORDER.

Early I 7 th century.

Scroll-like pattern in which the closely worked toile is arranged in upright designs forming escutcheons, strapwork and foliated forms; vandyked edge.

Length, 4 yards ${ }_{5}$ inches; width, I I inches.

BORDER.

$$
30
$$

Vertical, repeating designs of curved forms, filled in with lozenge pattern, these forms alternate with foliated scrolls.

Length, $x$ yard $3^{2}$ inches; width, $10 \frac{1}{2}$ inches.

BAS D'Aube. 3I Late i 7 th century. The principal features of the upright pattern are scroll forms showing early Rococo influence, alternating with a design of armorial bearings of lion and double-headed eagle, surmounted by a cross and papal crown. Details connected by a six-sided mesh.

Length, 5 yards 20 inches; width, 20 inches.

32

Bas D' Aube.

Late $7^{\text {th }}$ century.

The fine, tape-like toile is formed into detached, repeating designs composed of series of escutch- 
eons, strapwork and foliated forms. These details of ornament are connected by a six-sided mesh.

Length, 4 yards; width, 28 inches.

33

GARNITURE OF FOUR PIECES.

Early I 7 th century.

Irregular, zigzag designs are connected by double brides picotées. 


\section{MILANESE}

36

BORDER.

Late $17^{\text {th }}$ century.

The tape-like toile forms a pattern of continuous Raphaelesque scrolls, which are connected by a ground of hexagonal mesh.

Length, 2 yards 27 inches; width, 27 inches.

37

CuFf.

Late $17^{\text {th }}$ century.

Decorated with bold Renaissance scroll, the details being joined together with a four-sided mesh.

\section{8}

Border AND SMALL PIECE.

Middle 17 th century.

The toilé is formed into an upright, repeating pattern of a conventional foliated design. Details are connected by brides picotées.

Length, 3 yards $3 \circ$ inches; width, $8 \frac{1}{2}$ inches. 
BORDER.

Latter part i 7 th century. The toile forms a pattern of full and graceful branching scrolls with trefoil terminations. Details are joined with brides picotées.

Length, 4 yards 4 inches; width, $I_{3}$ inches.

\section{0}

Bas d'Aube.

Late $7^{\text {th }}$ century.

Large, irregular, repeating pattern, consisting principally of conventionalized acanthus leaves and pomegranates. These details are formed of a very fine, tape-like toilé, enclosing a variety of à jours.

Length, 3 yards 14 inches; width, 16 inches. 


\section{POINT D'ALENÇON AND POINT D'ARGENTAN}

7 HIS collection contains many examples of 1 the French school of point lace. These examples cover the whole period of its production, nearly a century and a half. France was indebted to Colbert for this school, as he was the prime mover in organizing a company under Royal patents, which established industries at Reims, Sedan, Aurillac, also at the old Normandy towns of Alençon and Argentan, for the purpose of making a lace to imitate Point de Venise. The first lace made under Royal patents was called Point de France, which closely resembled Point de Venise. The two laces differed only as to design. After a time, however, conditions favored the making of a new class of lace, which was of the réseau variety.

This lace was made principally at Alençon and Argentan, and became known as Point d'Alençon 
and Point d'Argentan. In Point d'Alençon the only constructive feature which was retained from the Venetian lace was the closely wrought, waxy toilé. The slightly raised cordonnet was stuffed with horsehair, which gave an effect of lightness to the relief. The mesh of Point d'Alençon ground was hexagonal, and resembled that of Brussels Point, with the exception that an extra thread was whipped around the top and bottom of the mesh. The ground of Point d'Argentan was also hexagonal, the sides being closely button-holed; aside from the grounds, the principles of construction of the two laces were identical. The method of making this French lace was most complicated. It was made in sections of ten inches; twelve people, each having his specific work, being required to complete a section. The different processes of construction were called le dessin, le picage, la trace, l'entoilage, le rempli, les brides or le réseau, les modes, la brode, l'enlevage and l'éboutage, le régalage and l'assemblage. During the third quarter of the seventeenth century the lace patterns were complex and ornate, combining Oriental, Italian and French designs. In the latter part of the reign of Louis XIV the lace patterns began to be distinctively French, showing the decorative features of the time. During the period of the Regency and of the reign of Louis XV the patterns consisted of garlands; vases and clusters of flowers, 
also Rococo scrolls, all of which gave to the lace an effect of grace and delicacy. In the reign of Louis XVI the decoration was confined mostly to the border of the lace, and consisted principally of paneled devices, enclosing modes, the main ground being ornamented at intervals with sprays of flowers or flowerets and sometimes circlets and dots. The Revolution sounded the knell of the French lace industries. Napoleon endeavored to revive them at the time of his marriage with Marie Louise, but was only partially successful. 


\section{POINT D'ARGENTAN}

ЈАвот.

Early I $7^{\text {th }}$ century. A large center panel of Oriental design forms the chief decoration; sprays of flowerets are arranged in and around the panel.

BORDER.

44

Pattern of festoons composed of conventionalized flowers, showing Oriental influence. The festoons form compartments which enclose pomegranates.

Length, I yard 5 inches; width, 3 inches.

\section{5}

Border in TWo pieces: Point de France.

Late 17 th century. A portion from a deeper piece. The edge is formed of leafage designs. Ground of hexagonal mesh à picots.

Length, I yard 25 inches; width, 2 inches. 


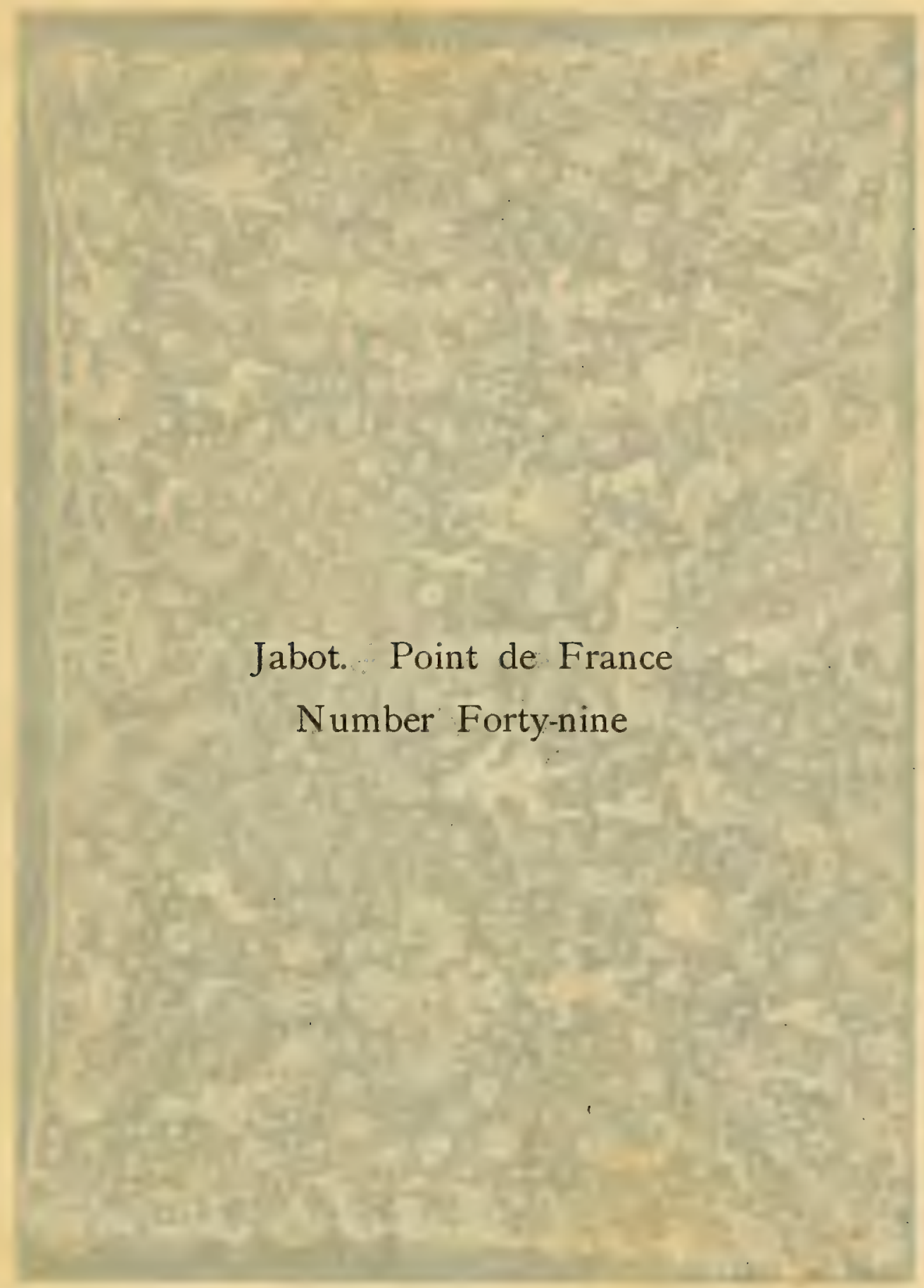




\section{Folse wirenthe}

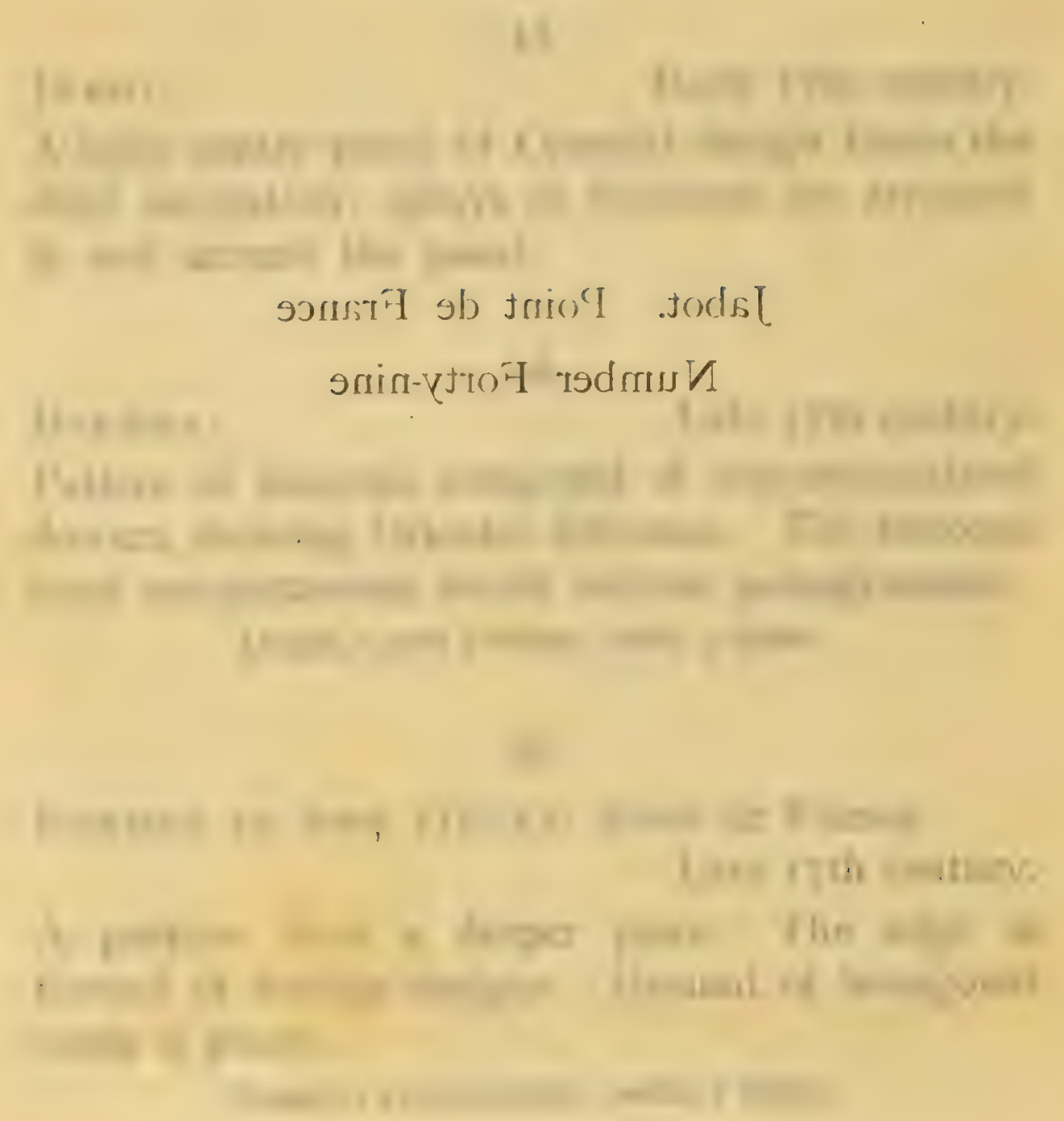




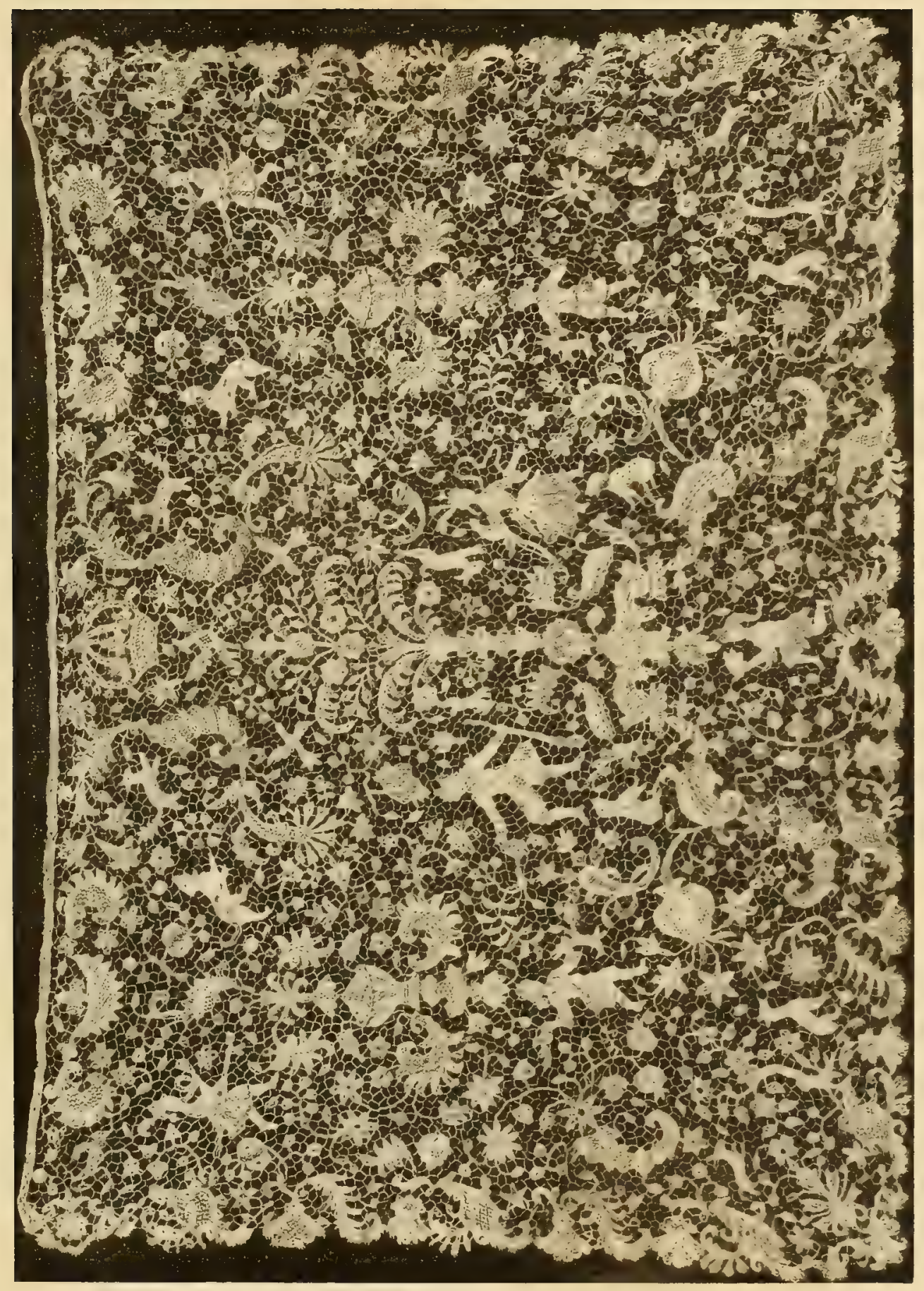



BORDER.

Decoration of bouquets of roses, pansies, and morning glories; these bouquets are entwined by a ribbon garland. Sprays of flowers spring from elaborate scroll border.

Length, 22 inches; width, 3 inches.

ЈАвот. $\quad 47$ Early I7th century. A center panel encloses a bouquet of flowers; the remainder of the button-holed ground is sprinkled with sprays of flowerets.

$$
48
$$

Border: Point de France. Late i 7 th century. The details of the ornaments are connected by a hexagonal, button-holed mesh à picots.

Length, I yard 22 inches; width, $\mathbf{1} \frac{1}{4}$ inches.

\section{9}

JАвот: Point de France. Late I 7 th century. The center shows a dove, the emblem of the order of Saint Esprit, surmounted by the crown of France. On either side are arranged people, subjects of the chase, and conventional floral ornamentation; these details are joined by a hexagonal mesh picotées. The jabot was probably made for some Royal personage of France.

Illustration. 
50

BORder: Point de France. Late I 7 th century. Ornamentation of conventionalized fruit and flowers connected by a six-sided mesh à picots.

Length, 26 inches; width, 7 inches.

$5 \mathrm{I}$

Flounce: Point de France. Late I 7 th century. A rare example of this class of lace. It illustrates the highest state of perfection to which the lacemaking industry attained in France, and shows the Eastern influence which characterized nearly all the designs of the French points of this period. The vertical pattern consists of a harmonious arrangement of conventionalized fruit and foliated features, also vases, and scroll designs. These details of the pattern are joined together by a hexagonal mesh à picots. Illustration.

Length, 2 yards 27 inches; width, 25 inches.

$5^{2}$

SMall piece.

Late $I$ th century.

Clusters of flowers are placed within diamondshaped compartments; the intervening spaces are filled with a hexagonal mesh and brides picotées. Length, $9 \frac{1}{2}$ inches; width, 3 inches. 


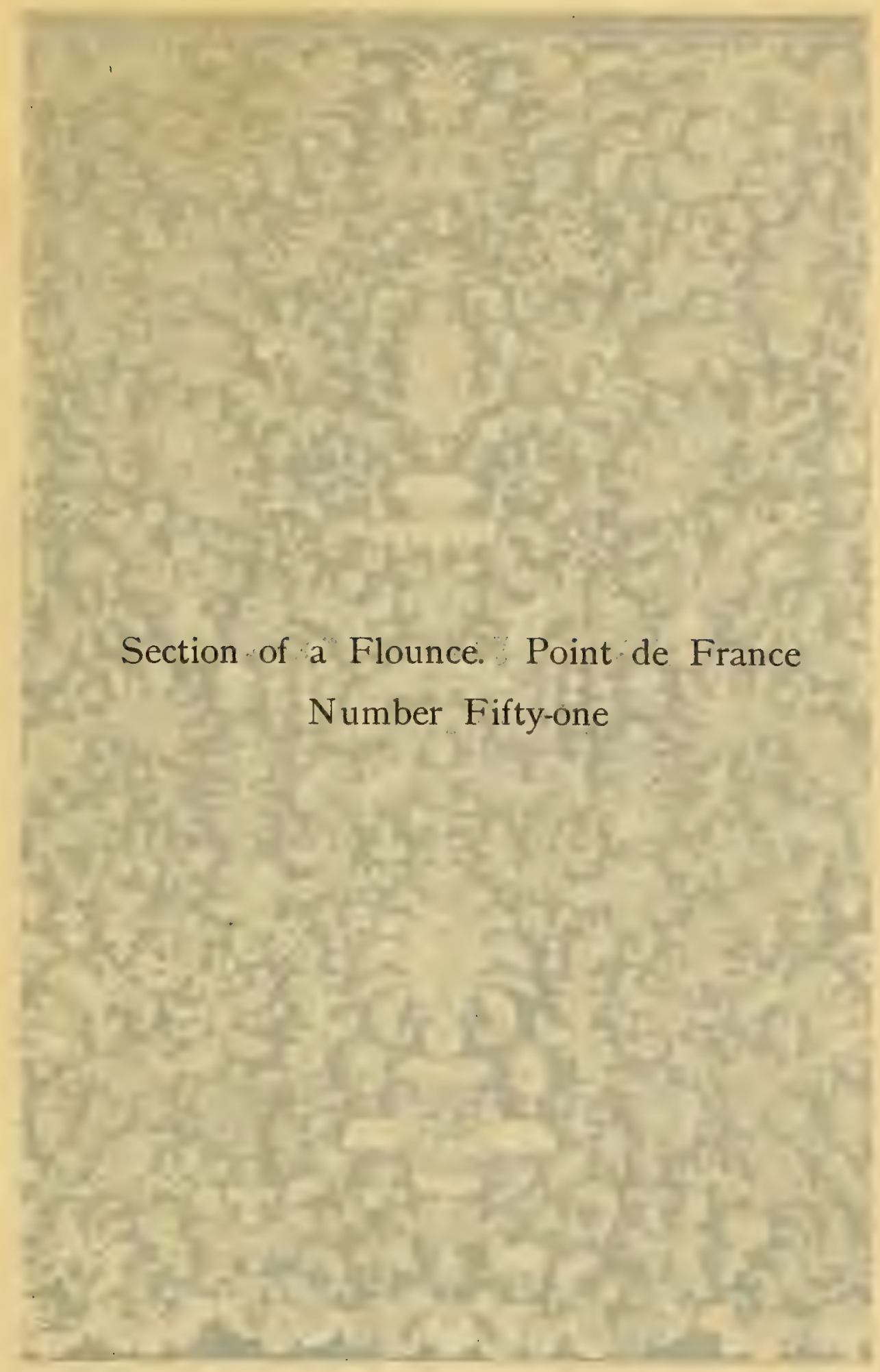




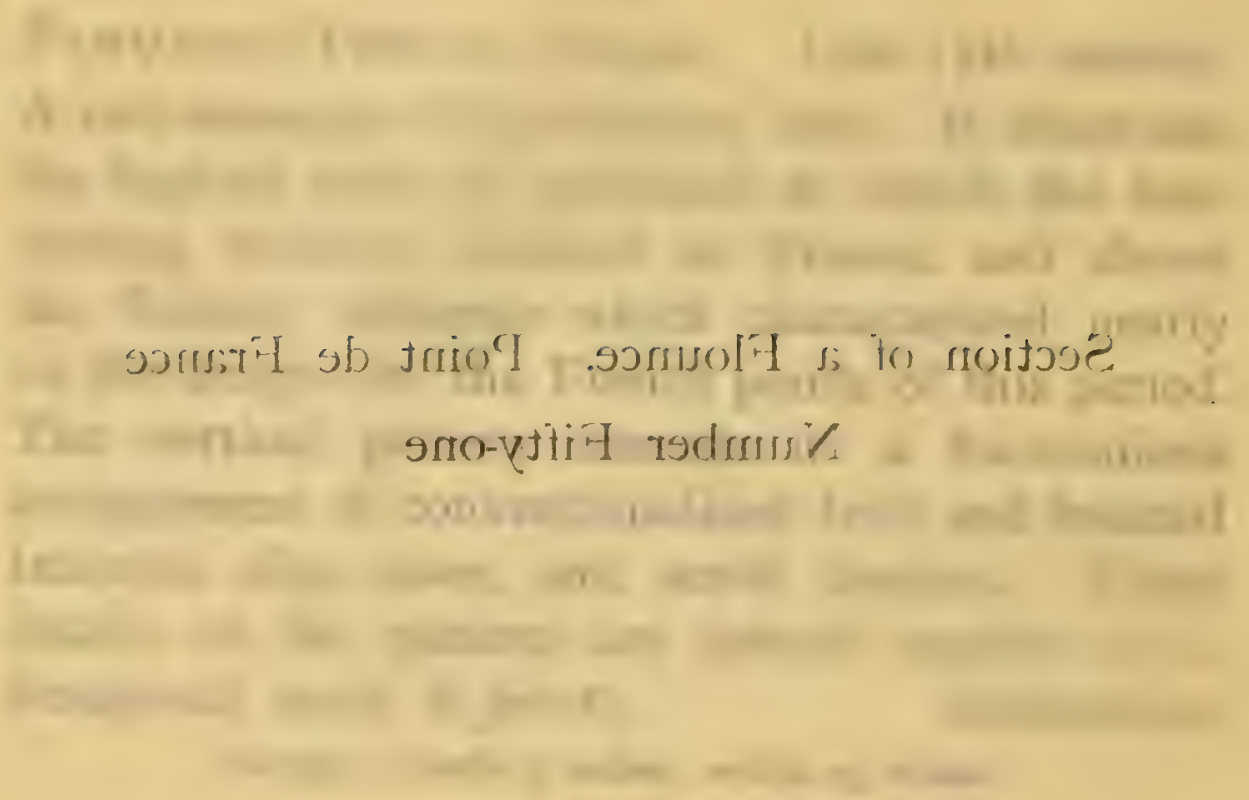

E

Hithe 


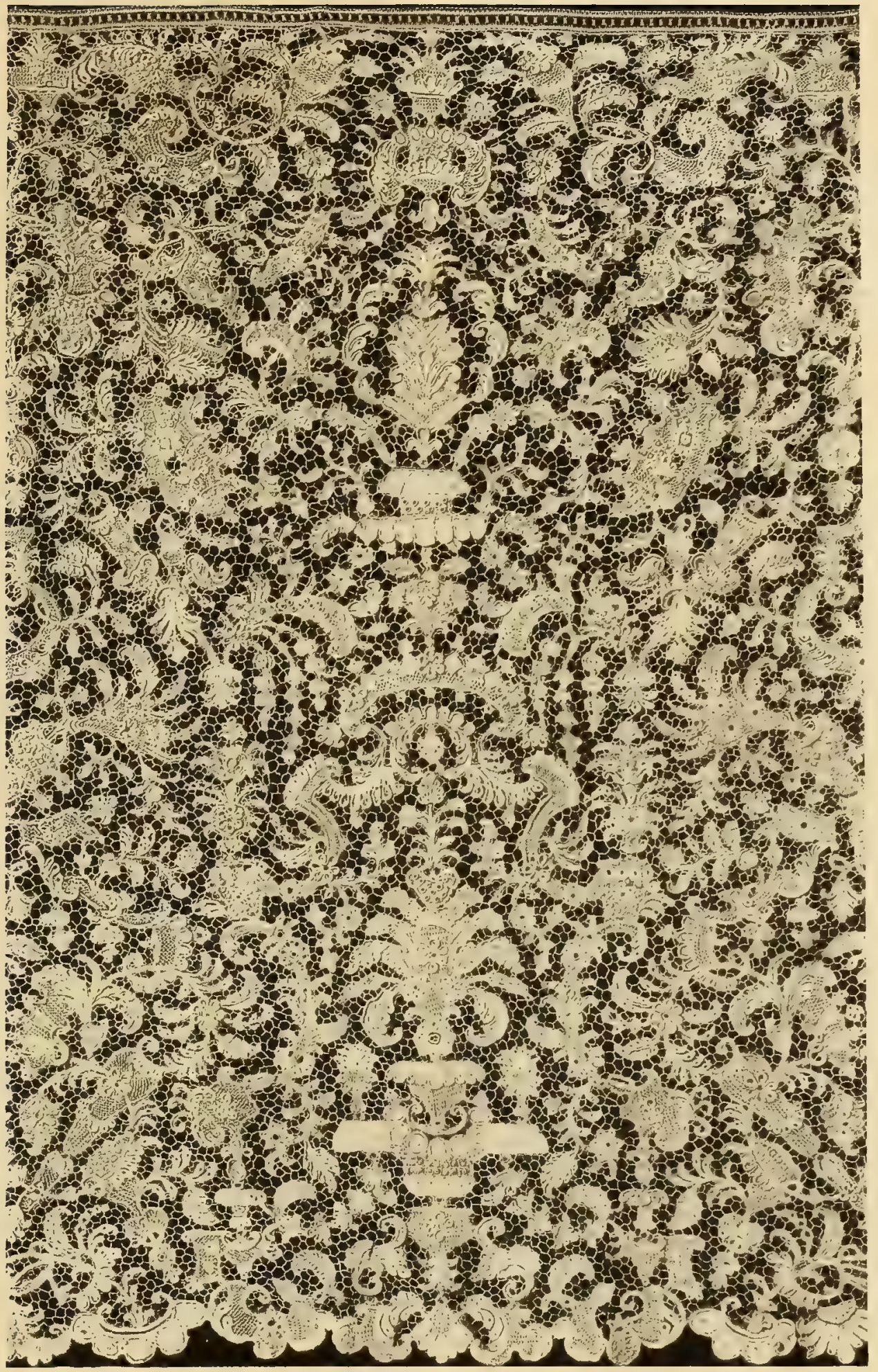



Јавот.

Period of the Regency.

Center panel enclosing sprays of flowers. The remainder of the hexagonal ground is ornamented by scrolls and flowerets.

\section{4}

Two SMall Pieces. Early i 7 th century. Regency scrolls form compartments which enclose modes.

BORDER. 55

Sprays of flowers and flowerets are placed alternately in triangular compartments. Border of scroll work enclosing à jours.

Length, I yard; width, 3 inches.

BORDER.

56

The edge ornamented by panels composed of delicate flowerets and scrolls.

Length, I yard 26 inches; width, $\frac{1}{2}$ inch.

BORDER.

Portion of a deeper piece. The principal decorative features appear on the edge, which consist of scroll panels enclosing a variety of fillings.

Length, 2-yards; - width, 2 inches. 
Border. $\quad 5^{8}$ Period of Louis XVI.

The principal decoration is placed on the edge, which consists of pinks, the stems being arranged to form panels enclosing a fine fond; clusters of pinks spring from these panels, and together with flowerets ornament the button-holed ground.

Length, 3 yards 2 inches; width, 4 inches.

BORDER.

59

Elaborate edge decoration of scrolls enclosing à jours. Sprays of flowers and flowerets ornament the ground.

Length, 3 yards 27 inches; width, 3 inches.

PORTION OF BARBE.
Graceful design of flowerets.

BORDER.

$6 I$

Decoration of sprays of flowers springing from a richly ornamented border.

Length, 3 yards 18 inches; width, 4 inches.

SCARF.

62

The button-holed ground is decorated with a pattern of long and graceful sprays of flowers, arranged 
in garlands and intermingled with scrolls and ribbon knots. The border of the scarf consists of floral and scroll panels which enclose a fine fond, also a variety of à jours.

BARBE.

Period of Louis XVI.

Rich border pattern of panels and floral decoration. The button-holed ground is ornamented with small floral sprays.

64

PAIR OF CUfFs.

Period of Louis XVI.

Ornamented with sprays of flowers and Rococo scrolls, which enclose a variety of intricate modes.

65

BORDER. Period of Louis XVI.

Graceful sprays of flowerets arranged as garlands form, with scrolls, the border design.

Length, 4 yards 18 inches; width, $3^{\frac{1}{2}}$ inches.

66

BARBE.

Period of Louis XVI.

Scroll border forming detached compartments which enclose alternating designs of clusters and wreaths of flowers.

Length, I yard I I inches; width, $3 \frac{1}{2}$ inches. 
BORDER.

This example has a simple border, consisting of guilloche and meander bands, above which is a row of scallops richly embellished with picots. The space between these details is filled with a fine réseau; ground covered with delicate sprays of flowerets.

$$
\text { Length, } 13 \text { inches; width, } 2 \frac{1}{2} \text { inches. }
$$

\section{8}

BORDER.

Period of Louis XVI.

Edge lace ornamented at intervals with small sprays of flowers.

Length, 29 inches; width, $\mathrm{I} \frac{1}{2}$ inches.

\section{9}

BORDER.

Period of Louis XVI. The edge is composed of sprays of flowerets. Flowerets are also scattered over the button-holed ground.

Length, 25 inches; width, 2 inches.

70

BORDER .

Period of Louis XVI.

Ornamentation of small sprays of flowers.

Length, 30 inches; width, $I \frac{1}{2}$ inches. 
BARBE.

Period of the Regency.

Bouquets of flowers and a series of irregular garlands of flowerets form the ornamentation. The border is of scroll work, with elaborate fillings. The fond at either end of the barbe is that of the regular Argentan ground, while the center has a fond which is not button-holed.

72

BORDER: Point de France. Late I 7 th century. Portion of some deeper piece. Ornamented with large, foliated designs.

Length, 40 inches; width, 2 inches.

BARBE.

Late I 7 th century.

Large vases of flowers and other details are placed without any unity of design; ground of hexagonal mesh à picots.

74

Collar: Point de France. Late 17 th century. Portion of a larger piece. Center filled with lattice work; large floral forms in Oriental style ornament the sides. The details are connected by a hexagonal mesh à picots. 


\section{POINT D'ALENÇON}

75

BORDER.

Period of Louis XIV.

Ornamental devices, arranged diagonally, form compartments which enclose clusters of flowers. Border of panels of scroll work, filled with a variety of modes.

Length, 3 yards 2 inches; width, 3 inches.

$$
76
$$

Three small pieces. Period of Louis XV. Pattern of sprays of flowers alternating with richly embellished scroll forms.

77

BORDER.

Period of the Regency. Elaborate pattern, consisting of detached compartments which enclose clusters of flowers. Edge of lace is ornamented by long panels formed of scrolls, and filled with various forms of à jours. Length, I yard 2 I inches; width, $3 \frac{1}{2}$ inches. 
BORDER.

Period of Louis XVI.

The principal decoration is in the vandyked edge, the points enclosing alternating wreaths and sprays of flowers; groundwork sprinkled with flowerets.

Length, 3 yards 23 inches; width, $3 \frac{1}{4}$ inches.

SMall PIECE. $\quad 79$ Period of Louis XV.

Ornate border of Rococo scrolls. Sprays of flowers and flowerets ornament the groundwork.

Length, 20 inches; width, 2 inches.

80

THREE PIECES.

Period of Louis XV.

Various ornamentations.

Length, 4 yards; width, $2 \frac{1}{2}$ inches.

$8 \mathrm{I}$

LAPPET AND THREE PIECES.

Period of Louis XVI.

Decoration of sprays of flowers, with panel border enclosing modes.

82

LAPpet and Jabot. Period of Louis XVI.

Border of lappet is formed by small panels composed of sprays of flowerets. The center ground is ornamented by floral sprays. The surface of jabot is sprinkled with bouquets. 
Fichu. Period of Marie Antoinette.

Border of fichu formed by panels alternating with series of stellati. The panels are filled with a fine fond, and are further enriched by elaborately wrought crossbars. Small devices are scattered over the groundwork.

BORDER.

84

Period of Louis XVI.

Pattern of sprays of flowers.

Length, I yard 5 inches; width, 2 inches.

BORdER.

85

Pattern of repeating cornucopias and floral sprays; vandyked edge.

Length, 3 yards 26 inches; width, $3 \frac{1}{2}$ inches.

86

BORDER.

Period of Louis XVI.

Ground ornamented by sprays of flowers, which spring both from the edge and the engrelure. The ground is further enriched by small clusters of leafage.

Length, 3 yards 3 inches; width, 3 inches.

Two PIECES.

87

Edge of scalloped scrolls enclosing a fine ground, which is ornamented with a band of guilloche 


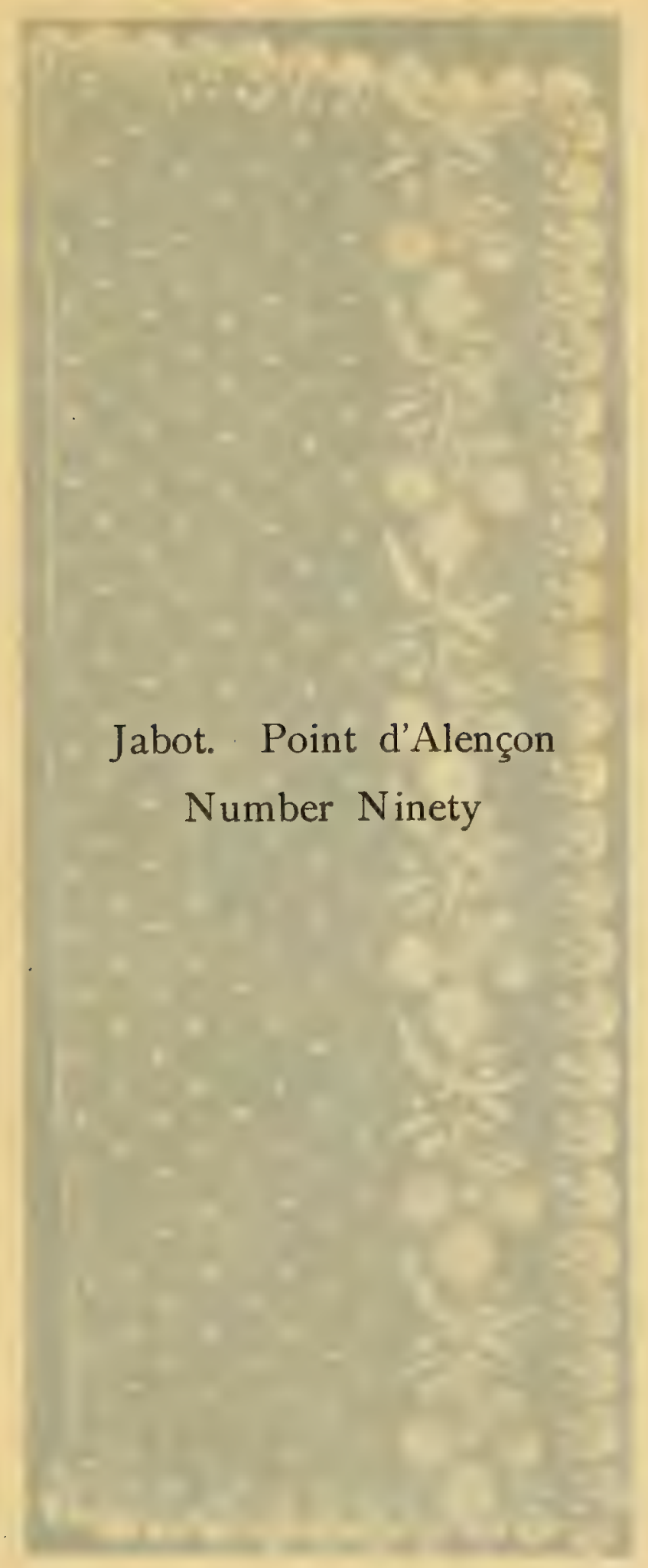




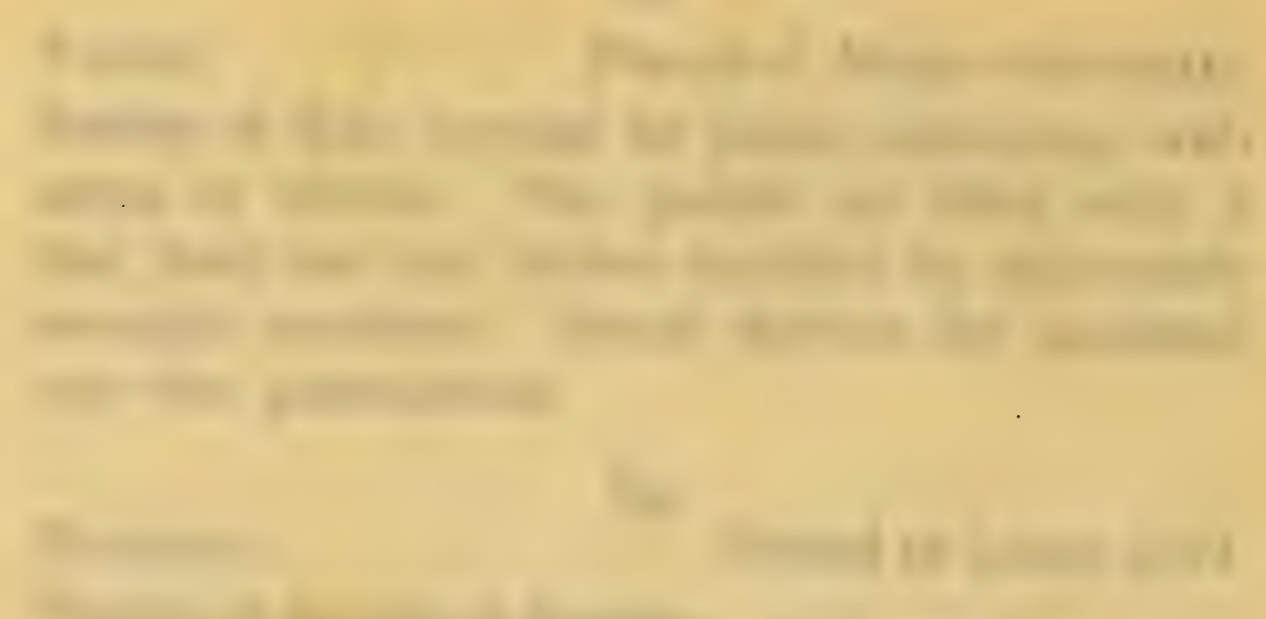

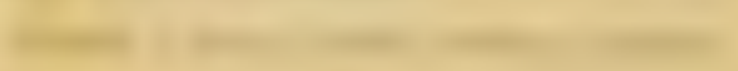

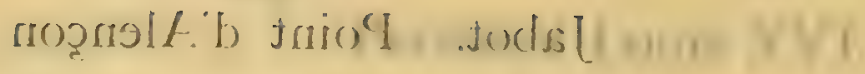

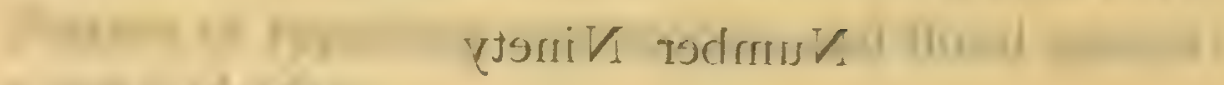
nomo4 sese

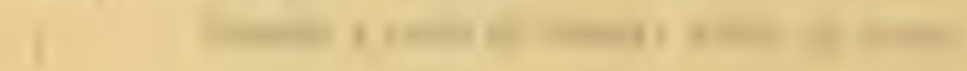

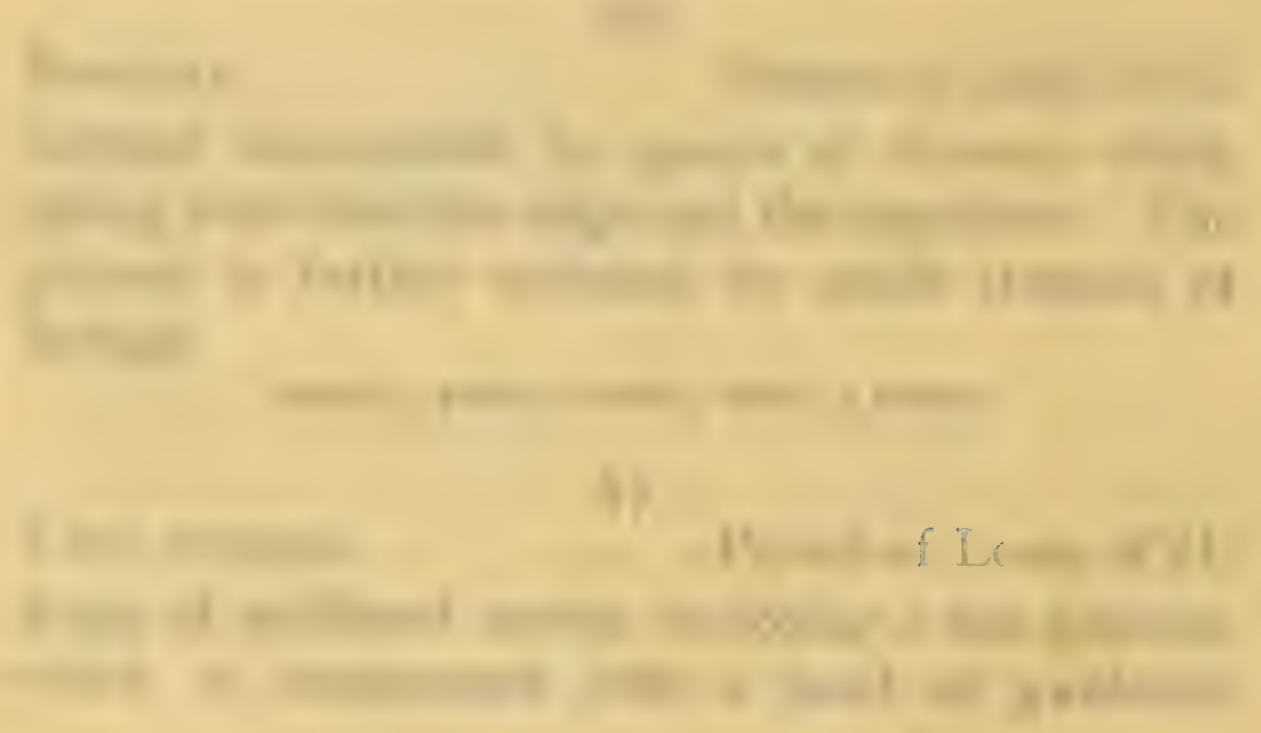




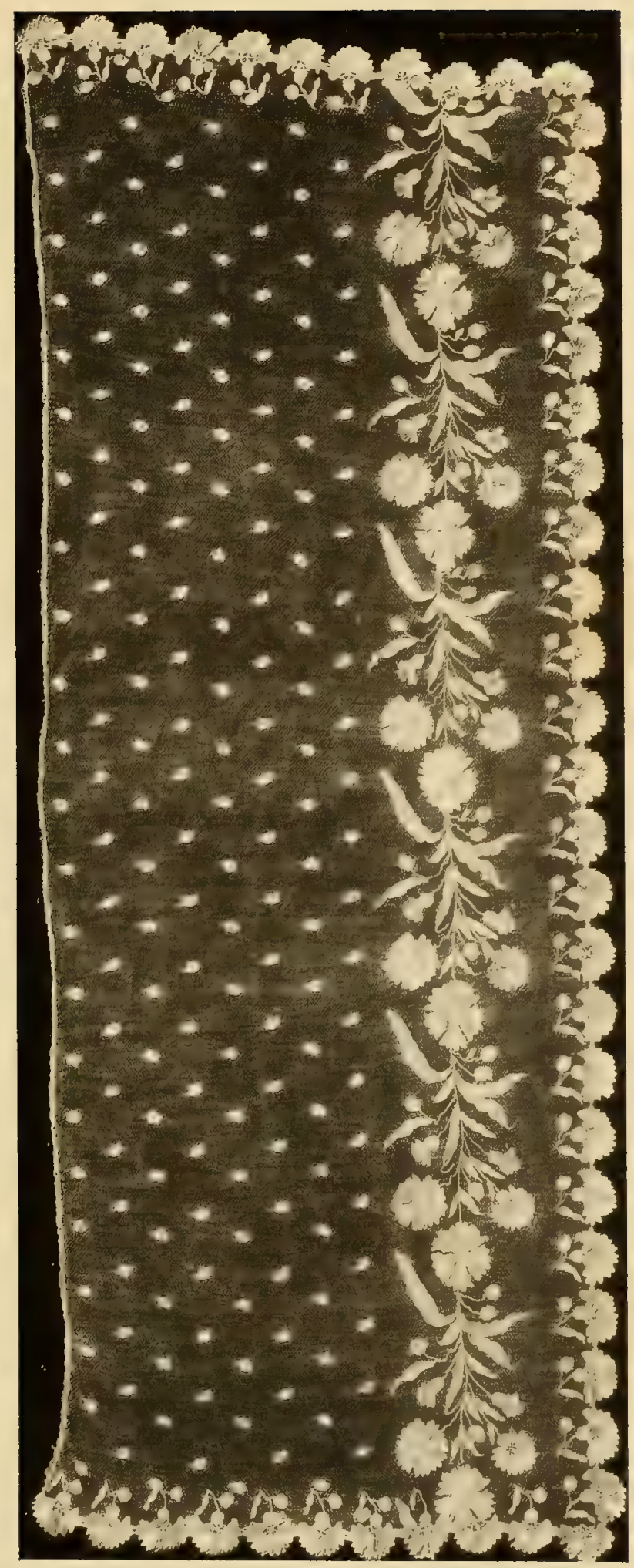



pattern. A rare feature of the lace is the embellishment of the cordonnet with picots.

BORDER.

Period of Louis XVI.

The edge is ornamented with leaf-like forms and small sprays of flowerets.

Length, 2 yards; width, $3 \frac{1}{2}$ inches.

89

BORDER.

Period of Louis XVI.

Edge is composed of a double row of oval panels enclosing a fine ground. Dots are scattered over the groundwork.

Length, 4 yards; width, $2 \frac{1}{2}$ inches.

JAвот. Period of Louis XVI.
Pattern composed of a band of repeating sprays
of cornflowers, with leafage. The same flower is
arranged on the edge, producing the effect of
ornamental scallopings.

9I

BORDER.

Period of Louis XVI.

Pattern of wreaths of flowerets placed at regular intervals over the ground. Edge of spiral bands.

Length, I yard 28 inches; width, 3 inches. 
92

LAPPET.

Period of Louis XVI.

Border formed of block-shaped panels, which enclose a fine ground; band of circlets intercepts the panels. Groundwork is sprinkled with flowerets.

93

BORDER.

Period of Louis XVI.

Edge of curved panels, surmounted by sprigs of flowerets. The groundwork is ornamented with floral sprays.

Length, 5 yards 33 inches; width, $3 \frac{1}{2}$ inches.

94

Jавот.

Period of Louis XVI.

Delicate sprays of flowerets, intermingled with dots, form series of large, conventional floral forms.

95

Six PIECES.

Period of Louis XVI.

Various ornamentations. 


\section{BRUSSELS}

$\mathrm{B}^{\mathrm{r}}$

RUSSELS was the oldest and most important lace of the Flemish school. The various schools of Flemish lace were usually named from the town which was the seat of the lace industry. Brussels itself was admirably adapted for a lace center, being situated, as it was, in the fertile province of Brabant, where the finest of flax was grown. During the seventeenth century Brussels lace was extensively made, and was always of a réseau variety. During the eighteenth century Brussels made both point and point d'application. The method of constructing Brussels was quite different from the method of constructing any other Flemish lace. The flowers, sprigs and various other details of ornament were made separately, and were then either set into the mesh, or the mesh was worked in between the details, or the details were applied to a ground. In Brussels pillow lace the long thread of the toile followed the line of the cordonnet; an outer thread surrounded the cordonnet to which the 
mesh was attached. The mesh of the pillow réseau was hexagonal, four sides being twisted, and the other sides being formed by plaiting four threads four times. When this réseau was made in narrow strips, it was called vrai réseau. The cordonnet of Brussels needle lace was button-holed only at intervals, and the mesh was formed of single threads and loops. A variety of Brussels lace was Point d'Angleterre, so named from the great popularity it attained in England during the latter part of the seventeenth century. This lace combined pillow-made details, connected by a vrai réseau, with a needle mesh used as filling for some of the details; this latter mesh was often embellished with picots. Portions of the pattern were sometimes applied to the vrai réseau. 


\section{BRUSSELS POINT}

IOO

BORDER.

Period of Louis XVI.

Ornamentation chiefly on the edge, and consists of wreaths and sprays of point on a pillow ground.

Length, 4 yards; width, 3 inches.

IOI

Two Lappets and TWo PIECES.

Period of Louis XVI.

Border pattern of devices resembling garlands; these devices are joined together by small clusters of flowerets, details are of point on a pillow ground. Length, 3 yards 18 inches; width, 3 inches.

$\mathrm{IO} 2$

Four pieces.

Modern.

Mixed needle and pillow lace.

Length, 5 yards; width, 2 inches.

Small Fichu.

103

Small and graceful sprays of point are applied to a pillow ground, panel border also of point. 
104

Small Fichu. Period of Louis XVI.

Pillow ground, over which are scattered dots of point.

105

Three PIECES. Period of Louis XVI.

Pattern of point in Louis XVI style, on a pillow ground.

Length, 2 yards 5 inches; width, 3 inches.

106

BORDER. Period of Louis XVI.

Cornflower pattern, with leafage of point applied to a pillow ground.

Length, 3 yards 17 inches; width, 3 inches.

107

BORDER.

Period of Louis XVI.

Ground ornamented at regular intervals with tiny floral devices of point.

Length, I yard 27 inches; width, 4 inches.

108

THREE PIECES.

Period of Louis XVI.

Vandyked edge and dots of point furnish the details of ornamentation.

Length, 2 yards 28 inches; width, 3 inches. 
109

HANDKERCHIEF.

Modern.

Of the variety of needle lace known as Point Gaze.

\begin{abstract}
I IO
VEIL.

About 1830 .

Border pattern of detached sprays of flowers, forming a scalloped edge. Directly over the border are large clusters of roses, with foliage; sprays of flowerets are scattered over the ground. All these details are of point. The réseau is made in narrow strips on the pillow, and is then joined together by a stitch called point de raccroc.
\end{abstract}




\section{POINT D'ANGLETERRE}

TWO PIECES.

Period of Louis XV.

Rococo scrolls are arranged in a wave-like device; these scrolls enclose a needle ground. The pillow réseau of the lace is ornamented with flowers.

I 6

BORDER.

Period of Louis XV.

Pattern of Rococo scrolls intermixed with floral forms.

Length, 2 yards 27 inches; width, 3 inches.

I I 7

BORDER.

Period of Louis XV.

Edge pattern of scrolls, forming compartments; ground decorated with floral sprays.

Length, 32 inches; width, 3 inches.

I I 8

Three PIECES.

Period of Louis XV.

Patterns of various designs. 
I 19

Three small pieces. Period of Louis XV. Principal feature of the design consists of wavelike scrolls, which are filled with a needle mesh. These scrolls form triangular compartments, in which are placed sprays of flowers and leafage.

Length, 3 yards 16 inches. 


\section{BRUSSELS PILLOW LACE}

I 2 I

BORDER.

Period of Louis XIV.

Pattern of pomegranates, with buds and leafage, showing Persian influence.

Length, 4 yards II inches; width, 5 inches.

\section{22}

Border IN TWo pIEces. Period of Louis XV. Foliated details and small interlacing scrolls are placed without forming special designs.

Length, 2 yards 7 inches; width, 3 inches.

\section{23}

BORDER.

Period of Louis XV.

Pattern of alternating designs of harp-shaped ornaments and palm leaves. Border of scrolls, filled with a variety of $\grave{a}$ jours. Needle ground.

Length, 2 yards 30 inches; width, 3 inches. 
SMALl PiECE.

Period of Louis XV.

Designs of floral forms and scrolls, the details being connected by brides picotées.

Length, $2 \mathrm{I}$ inches; width, 2 inches.

I 25

Two SMALl PIECES.

Period of Louis XIV.

Foliated details, which are connected by a variety of grounds.

Length, 30 inches; width, 2 inches.

$$
\text { I } 26
$$

JАBOT.

Period of the Regency. Center design of escutcheon, enclosing flowers. A bouquet of flowers surmounts the escutcheon. Border of scrolls, filled in with a variety of modes.

127

PAIR OF LAPPETS.

Period of the Regency. Ornate floral scroll pattern. The lappets are connected by a strip of border lace of the same pattern, the details being joined in part by brides picotées.

$$
\text { I } 28
$$

LAPPET.

Period of Louis XVI. Foliated pattern showing Eastern influence. The centers of many of the details are filled in with modes. 
BORDER. Period of Louis XVI.

Edge design of small conventional flowers, placed vertically; ground studded with star-like forms.

Length, 5 yards 4 inches; width, 3 inches.

EDGING.

I 30

Period of Louis XVI.

I 3 I

CORPORAL. Period of Louis XVI.

Decoration of parallel bands of floral sprays, with leafage. The bands are connected by a needle ground. This example, both as to workmanship and design, is representative of the best eighteenth century work of the Brussels school.

132

BORDER.

Period of Louis XVI.

Edge pattern of alternating sprays of flowers and flowerets. Dots are scattered over the needle ground.

Length, 2 yards; width, 4 inches.

I 33

BRIDAL VeIL.

Early I9th century.

Veil nearly circular in form, edge and inner border ornamented with a graceful, continuous pattern of 
sprays of roses and carnation pinks, with foliage. Sprays of roses, leafage and flowerets are scattered over the center of the needle ground.

\section{I34}

BORDER IN SIX PIECES.

Design of flowers, on a needle ground of peculiar construction. Graceful, scalloped edge.

Length, 4 yards; width, $6 \frac{1}{2}$ inches.

135

CAP MADE OF LACE. Early I9th century. Roses and leafage massed together without forming a pattern, and united by brides picotées.$$
136
$$

Two PIECES. Middle igth century.

Designs show a mixed style, embodying features of the Louis XIV and Regency periods. Needle ground.
}

JАвот.

Middle Igth century.

Floral and leafage details are placed without regard to any special pattern. Border of the edelweiss. The details are connected by brides picotées. This jabot is formed of several pieces of lace of the same pattern. 
Flounce.

Period of Louis XV.

Elaborate fan and scroll pattern, which is suggestive of a Point d'Argentan design. The details of the fan design are connected with an cil de perdrix ground; the other details are joined by Brussels mesh à picots, tape-like bars connected by brides, and a hexagonal mesh.

Length, 4 yards 20 inches; width, $10 \frac{1}{2}$ inches.

I 39

NARROW PIECE OF LACE.

Same period and design as Number 138.

Length, I yard 8 inches; width, 5 inches.

I 40

Flounce in tWo pieces.

Period of Louis XV.

Repeating, detached pattern, composed of pomegranates and scroll forms, the details being filled in with various a jours. The ground is the Brussels pillow réseau.

Length, 6 yards 18 inches; width, 6 inches.

\section{4 I}

TWO SMALL PIECES.

About I80o.

Design of pomegranates and other Oriental features, which are connected by brides picotées.

Length, I yard 3 inches; width, $\mathrm{I} \frac{1}{2}$ inches. 
142

Small pieces.

Period of the Regency.

Design of cornucopias, alternating with foliage and Rococo scrolls of fine workmanship; details of the pattern connected with a Brussels ground.

Length, I yard 12 inches; width, 3 inches.

I 43

BARBE.

About I 830.

Very fine toilé, giving effect of light and shade. Barbe is narrower in the middle and gradually widens towards the ends, center being filled with needle mesh. 


\section{GUIPURE DE FLANDRES}

DUGES may be said to have been the home $\mathcal{B}$ of the guipure de Flandres. This variety was the only Flemish lace belonging to the tape class, and it closely resembled Genoese and Milanese of the same class. It originated about the same time, and in order to distinguish between this lace and the Italian, it is essential to be familiar with the different treatment of the same design in Italy and Flanders. The treatment of the Italian design was marked by greater freedom than that of the Flemish. 


\section{GUIPURE DE FLANDRES}

I 48

Flounce.

Middle I 8 th century. Medallion and flower pattern, which suggests both Eastern and Italian influence; the principal details enclose a variety of à jours.

Length, 4 yards; width, ro inches.

\section{49}

BORDER.

Middle igth century.

Design of medallions and floral forms.

Length, 2 yards; width, $3 \frac{1}{2}$ inches.

\section{50}

Flounce.

Period of the Regency. The tape-like toile is formed into an irregular, zigzag pattern, which is carried well into the scalloped border. Hexagonal plaited mesh.

Length, 3 yards 18 inches; width, 9 inches. 
FlounCE IN FOUR PIECES. I th century. The scheme of ornamentation consists of foliated and scroll forms, details of which are connected by a hexagonal twisted mesh.

Length, 4 yards; width, $7 \frac{1}{2}$ inches.

152

BORDER.

Early i 8 th century. Graceful foliated pattern, which, terminating at intervals in the border, forms with other details a scalloped edge. This example closely resembles the Point plat de Venise of the seventeenth century. Hexagonal plaited mesh.

Length, 3 yards 4 inches; width, 3 inches.

\section{53}

BORDER.

Middle I 8 th century. Similar variety to Number 152 , but in this example the edge is vandyked, and is of quite a different design from that of the body of the lace.

Length, 2 yards 15 inches; width, $2 \frac{1}{2}$ inches. 


\section{BINCHE}

\footnotetext{
D INCHE, like Valenciennes, was a town of the old province of Hainault, and produced a variety of lace similar to the Valenciennes; and, as in the case of that lace, the toile of the pattern had no cordonnet, or, if any, it was almost imperceptible. The distinctive feature of Binche lace was the irregular ground, which was usually of the fond de neige variety rather than of a réseau nature. In some examples the pattern was so indefinite as to give the lace the appearance of a web-like texture.
} 


\section{BINCHE}

I 55

BORDER.

I 8 th century.

Repeating pattern of sprays of flowers, details connected by web-like ground.

Length, 2 yards 18 inches; width, $2 \frac{1}{2}$ inches.

BORDER.

I 56

Long, foliated scroll pattern, terminating in scalloped border, the intervening ground being composed of a variety of irregular meshes.

Length, 7 yards; width, 2 inches.

BORDER.

I 57

Ornate design of the Regency. Elaborate details connected by a distinctive Binche ground.

Length, I yard 9 inches; width, $\frac{1}{2}$ inch. 


\section{MECHLIN}

$\mathrm{M}^{\mathrm{s}}$

ECHLIN was, next to Brussels, the most important of the pillow laces of Flanders. The toilé of the pattern was outlined by a cordonnet of flat strands of thread. A feature of the toilé was, that the long thread ran parallel to the edge of the lace, and did not follow the line of the cordonnet. The mesh was hexagonal, four sides being twisted, and the other two formed by plaiting four threads three times. The toilé and mesh of Mechlin were made together on the pillow. The patterns of the eighteenth century Mechlin closely followed those of the Point d'Alençon of the same period. Mechlin was a favorite court lace, its delicate, gossamer-like texture commending it especially for use as lappets and ruffles. 


\section{MECHLIN}

I 59

Border IN TWO PIECES. Middle I 7 th century. Pattern of irregular scrolls, arranged so as to form compartments. Edge of panels, filled in with a quatrefoil device.

Length, 3 yards 27 inches; width, 2 inches.

160

LAPPET.

Period of the Regency.

Elaborate border of Regency scrolls form compartments, which enclose cornucopias and flowers.

I6I

LAPPET.

Period of Louis XV.

The principal motif of the pattern consists of scrolls arranged to form triangular compartments, the intervening spaces containing sprays of flowers. Border is enriched by panels, enclosing devices in lattice work.

Length, I yard 9 inches; width, 3 inches. 
I62

LAPPET.

Period of the Regency. Zigzag pattern of foliated forms ornaments the center. Along the sides of the lappet are simple scrolls, enclosing a variety of grounds.

\section{3}

BORDER.

Period of the Regency. Same pattern as Number 162, forming, with the lappet, a garniture.

Length, 3 yards 4 inches; width, $2 \frac{1}{2}$ inches.

I64

Cravat.

Period of Louis XVI.

Made of edging and insertion. Flowerets are scattered over the ground of the lace. The border consists of sprays of roses.

165

BORDER.

Period of Louis XVI. Small sprays of flowers form a graceful edge; dots are scattered at regular intervals over the groundwork.

Length, I yard 27 inches; width, 3 inches. 
BORDER. Period of Louis XVI.

Ground covered with a graceful, vertical pattern of roses with foliage; edge of scrolls, enclosing a variety of $\grave{a}$ jours.

Length, 3 yards 18 inches; width, $5 \frac{1}{2}$ inches.

$$
167
$$

BORDER.

Period of Louis XVI.

Sprays of flowers are scattered at regular intervals over the body of the lace. Scalloped edge, each scallop enclosing a palm leaf.

Length, I yard 30 inches; width, 5 inches.

I68

BORDER.

Period of Louis XVI.

Pattern of clusters of gentians. A deep scalloped border design consists of a graceful arrangement of roses and buds.

Length, 4 yards 18 inches; width, $4 \frac{3}{4}$ inches.

I69

BORDER.

Period of Louis XVI. Edge pattern of clusters of gentians. Tiny floral devices are placed at regular intervals over body of lace. 
170

BORDER IN TWO PIECES. Early I9th century. The chief motif of the pattern consists of a repeating geometric form; above the forms are small floral devices. The scalloped border is formed by the graceful intertwining of leaves and scrolls.

Length, 3 yards 12 inches; width, $3 \frac{1}{2}$ inches.

17 I

CAP MAdE of LACE. Period of Louis XVI. Pattern of clusters of roses; edge of single roses.

172

Two small pieces. Period of Louis XVI. Pattern of scrolls arranged to form compartments, which enclose floral sprays. 


\title{
TROLLE KANT
}

\author{
A TERM applied to a peculiar old Flemish \\ A lace, in which the cordonnet of the pattern \\ was very prominent, and consisted of a \\ heavy, coarse thread loosely run around the toile, \\ thereby giving the lace its name. \\ Another characteristic of this lace was the variety \\ of grounds. The production of Trolle Kant was \\ not confined to any one locality. It was usually \\ made in the suburbs of lace-making centers.
}




\section{TROLLE KANT}

I 75

BORDER.

Period of Louis XIV.

Pattern of open scrolls arranged to form compartments, which enclose sprays of flowers. Ground variously filled in.

Length, 2 yards ; width, $2 \frac{1}{2}$ inches.

$$
\text { I } 76
$$

BORDER.

Period of the Regency. Pattern of repeating, detached Regency scrolls, enclosing latticework; between these scrolls are arranged floral sprays. Ground of cinq trous mesh.

Length, 7 yards; width, 2 inches.

177

BORDER.

Period of the Regency. Pattern of Regency scrolls, ground consisting of a web-like mesh.

Length, 2 yards; width, $1 \frac{3}{4}$ inches. 


\section{78}

BORDER.

Period of Louis XVI.

Pattern of repeating medallions, formed of palmleaf-shaped ornaments and flowers. Ground variously filled in.

Length, 4 yards $x 8$ inches; width, 2 inches.

I 79

BORDER.

Period of the Regency.

Pattern of scroll-like devices. Mixed ground.

Length, 3 yards; width, 2 inches.

I 80

TWO PIECES.

Period of the Regency.

Scroll pattern, connected by a cinq trous mesh.

Length, 4 yards; width, $\mathrm{I}_{\frac{1}{2}}$ inches.

\section{8 I}

Plastron and Pair of Cuffis.

Late 17 th century.

Repeating pattern consists principally of alternating medallions, enclosing floral sprays. These medallions are connected with other details of the pattern by cil de perdrix, Binche and cinq trous grounds.

$$
\text { I } 82
$$

BORDER.

Period of Louis XIV. Pattern of sprays of flowers and scrolls, the details being connected by a cinq trous mesh.

Length, 12 yards; width, 2 inches. 


\section{VALENCIENNES}

$\mathrm{O}$

$\mathrm{NE}$ of the oldest varieties of Flemish lace was the Valenciennes, named for a town in the old province of Hainault. During the early and middle part of the seventeenth century the lace was called fausse Valenciennes. The pattern was marked by severity and formality of design; the ground consisted of a variety of meshes. From the latter part of the seventeenth century the pattern was largely influenced by the decorative features of the various periods, and the mesh was lozenge-shaped, every side being plaited. This lace was called vrai Valenciennes.

Valenciennes lace had no cordonnet. The pattern and ground were made together on the pillow. As in the case of other Flemish laces, the best examples were made within the town walls. 


\section{VALENCIENNES}

$$
\text { I } 85
$$

SMall Piece. Late 17 th century. Of the variety called fausse Valenciennes. Cinq trous ground.

$$
\text { I } 86
$$

BORDER.

Late $17^{\text {th }}$ century.

Of the variety called fausse Valenciennes. The pattern consists of palm-leaf-shaped ornaments and foliated sprays; details connected with various grounds.

Length, 5 yards 12 inches; width, 2 inches.

$$
\text { I } 87
$$

BORDER.

Late I 7 th century. Pattern of birds in flight alternating with vases of pinks, the toilé of the details being of great fineness of workmanship; edge of small scrolls.

Length, 2 yards; width, 2 inches. 
BORDER.

Period of Louis XIV.

Pattern of sprays of flowerets on a vrai Valenciennes ground; edge of scroll work.

Length, 3 yards; width, 2 inches.

I 89

Two SMALl PIECES. Period of Louis XVI. Border pattern of detached conventional roses, which are placed in the points of the vandyked edge. Small scroll devices are placed at regular intervals on the body of the lace.

Length, I yard 12 inches; width, 2 inches.

I 90

BORDER.

Late I 8 th century.

Ground ornamented with bouquets of flowers; border, lambrequin style, with scalloped edge. Two sides of the lozenge-shaped mesh are twisted and two are plaited.

Length, 5 yards 18 inches; width, 5 inches.

I9I

BORDER.

Late I 8 th century.

Lambrequin design, same as in Number 190. Ground of vrai Valenciennes.

Length, 2 yards; width, 4 inches. 
192

SMall PIECE.

Period of Louis XVI.

Simple decoration of sprays of flowerets; ground sprinkled with dots.

BORDER.

Late I 8th century.

This example is a piece of English Buckinghamshire lace, made to imitate Valenciennes, and known as Baby Lace. The mesh, instead of being lozenge-shaped, is hexagonal. Lace of this kind was also made at Dieppe.

Length, 4 yards; width, 2 inches. 


\section{SPANISH}

CPAIN was not a lace-making country to the $\checkmark$ same extent as were Italy, Flanders, and France. Spain was content to import most of her laces, and being closely allied to Flanders she naturally obtained her pillow laces from that country. Her points were purchased mainly from Italy. The lace that was made in Spain was more the work of nuns in convents than the product of industrial schools. 


\section{SPANISH}

$$
\text { I } 96
$$

Collar and three small pieces:

Punto Tagliato a Fogliami. Late I 7 th century. Pattern of foliated scrolls, the details being enriched with a raised cordonnet. Many of the details are further enriched by a superposed device formed by raised button-hole work. Details are connected by brides picotées.

\section{I97}

Length: Punto Tagliato a Fogliami.

Late $17^{\text {th }}$ century. Scroll pattern treated in the Spanish style.

Length, I yard 16 inches; width, 4 inches. 


\section{MANILA}

$7 \mathrm{HE}$ needlework from the Philippines may 1 be classed as embroidery rather than lace. The Filipinos have for many years woven a tissue from the fiber of the pineapple plant, also from a certain kind of grass. This tissue was used as the foundation for embroidery and drawn work. 


\section{MANILA}

200

SCARF.

About 1830 .

Foundation of pineapple cloth, ornamented by a distinctively Oriental design of drawn work and embroidery.

$20 \mathrm{I}$

VEIL.

About 1830 .

The foundation is well covered with a design of spreading flowers; portions of the flowers are cut away, and the space is filled in with a mesh resembling that of Lille lace.

202

HANDKERCHIEF.

About I 830.

Ornamented with drawn work and embroidery. 


\section{CHANTILLY}

OHANTILLY black lace was made of a hand-twisted silk. The method of twisting the silk gave it the appearance of flax. For this reason Chantilly was often called thread lace. The mesh of the older Chantilly was made in strips, which were joined by point de raccroc.

The toile of the pattern was outlined by a flat, untwisted strand of thread. Chantilly was also made at Bayeux. 


\section{BLACK CHANTILLY}

Flounce.

203

Ground covered with sprays of flowers and leafage, which spring directly from the border; scalloped edge.

Length, 4 yards 27 inches; width, 22 inches.

BORDER.

204

Upright border pattern forming panels, which enclose clusters of flowers.

Length, 8 yards; width, $4 \frac{1}{2}$ inches.

BORDER.

205

Pattern of small, foliated sprays; scalloped edge.

Length, 5 yards 18 inches; width, 4 inches.

BORDER.

206

Border pattern of roses, alternating with leafage and scrolls.

Length, 16 yards ; width, $2 \frac{1}{2}$ inches. 
BORDER.

Middle igth century.

Typical pattern of the period, showing festoons of drapery and upright sprays of flowers.

$$
208
$$

BORDER.

Late I9th century.

Edge pattern composed of groups of triangular forms, alternating with clusters of flowers, details being connected by strapwork.

Length, 6 yards 27 inches; width, 4 inches.

209

BORDER.

Late igth century.

Pattern of sprays of flowers gracefully arranged; scalloped edge of roses.

Length, 7 yards 18 inches; width, $3 \frac{1}{2}$ inches.

210

Pair of Lappets. Second half of Igth century. Centers filled with a series of escutcheons, enclosing clusters of flowers; outer edge of flowers.

\section{I I}

BORDER. Latter part of Igth century. Rich border of festoons and garlands of flowers. The main ground is ornamented at intervals with foliated sprays.

Length, 2 yards; width, 4 inches. 
ThrEE-CORNERED SHAWL.

Period of Second Empire.

Center filled with large and elaborate bouquets of flowers. Border of scrolls intermingled with leafage, the details being connected at intervals with strapwork. The workmanship is very fine, and the toilé shows an effect of light and shade.

213

Flounce in two pieces.

Period of Second Empire. The pattern consists of repetitions of two vertically arranged groups of arbor-like canopies, also flowers intermixed with scrolls.

Length, 8 yards 18 inches; width, 20 inches. 


\section{GLOSSARY}

$A$ picot, brides picotees. Terms referring to the uses of the picot.

$\dot{A}$ jours. Similar to modes, although of a more open and elaborate nature.

Brides. Short length of threads used to connect the details of a pattern. The threads may be buttonholed, twisted, overcast, or loose. The button-holed brides are often enriched with picots.

Cing trous. A peculiar kind of plaited hexagonal mesh, used mostly in old Flemish laces. It is thus named from the fact that the vertical sides of the meshes are separated by a division formed of threads so plaited as to leave five holes in the division.

Cordonnet. A thread or threads, either twisted, buttonholed, or overcast, used to edge or outline the details of the pattern. This outline may be on an even surface with the toile, as in Mechlin, or it may be slightly raised, as in Point d'Alençon. Again, it may be in high relief, as in Gros Point de Venise. 
Engrêlure. A narrow band of pillow or needle work sewed to the main piece of lace for the purpose of attaching it to any desired material.

Fond. A fine réseau.

Fond de neige. A ground of a web-like nature.

Guilloche. An interlacing band of ornament.

Guipure. The term guipure is used to designate any lace where the details of the pattern are connected, either by a coarse ground or by brides, or where the various details are joined directly to one another.

Meander. A fret band in which the lines forming the design do not interlace. Both the guilloche and meander are ancient forms of Greek ornament.

Modes. Ornamental stitches used in filling in the open spaces of the details of the pattern.

Eil de perdrix. A large, hexagonal mesh enclosing a smaller, similarly filled mesh, the two being connected at the angles by single threads.

Point de raccroc, or fine joining. A stitch used in joining narrow sections of pillow réseau. These sections are from one-half to one inch in width.

Picot. A name applied to a small loop formed by a single twist of a thread, as in pillow lace, or by buttonholing, as in needle lace. The loops are used singly or collectively in finishing the edge of the lace, or may be used in embellishing cordonnet, brides, and various details of the relief.

Rabato. A cravat worn by high dignitaries during the seventeenth and eighteenth centuries. 
Réseau. A ground of network composed of small, regular meshes, made either on the pillow or with the needle.

Rococo. The term Rococo is used in describing an object in which various details of ornamentation, that have no relative harmony, are placed in juxtaposition.

Stellati. Picots arranged in star-like forms.

Toile. That part of the pattern enclosed by the cordonnet, which is closely filled, giving the effect of cloth.

Vandyke. A term used to describe pointed edges. In the sixteenth century a Flemish mechanic by the name of Vandyke added a contrivance to a stocking frame, by means of which the ribs of the stocking were made to form zigzags, which were called vandykes. Thus the term was derived. 


\section{DEFINITIONS OF TERMS USED IN DESCRIBING THE PROCESSES OF MAKING POINT D'ALENÇON LACE}

Le dessin. The drawing of the design on the parchment upon which the lace is made.

Le picage. The pricking of the design on the parchment.

La trace. Outlining the details of the design by means of a thread which is secured to the parchment by other threads.

L'entoilage. Filling in of the details which form chief motif of design.

Le rempli. Filling in of minor details.

Les brides. Large, button-holed meshes, which form a ground.

Le réseau. Ground of small meshes.

(One or the other of these grounds was used, sometimes both, as in certain Point d'Argentan lace.)

Les modes. Ornamental fillings.

La brode. The closely button-holed, raised cordonnet.

L'enlevage. Cutting the lace free from the parchment. 
L'éboutage. Drawing out the threads which secured the outline.

Le régalage. Repairing any defects made by cutting away the lace from the parchment.

L'assemblage. The joining of the various sections. 








SMITHSONIAN INSTITUTION LIBRARIES

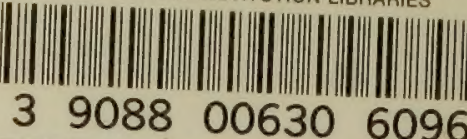

